\title{
TINJAUAN KEDUDUKAN PENGGUNA ANGGARAN \\ DAN KUASA PENGGUNA ANGGARAN
}

\author{
Laurensius Arliman S \\ Sekolah Tinggi Ilmu Hukum (STIH) Padang \\ Jl. AR. Hakim No 6 Padang \\ Email: stih_pdg@yahoo.co.id
}

\begin{abstract}
This research aims to discuss the Status Users Budgets and the Budget User Proxy and Its Implications. This paper uses normative research. Results of this writing, the Regulation number 21 of 2011, or a change to a 2 Regulation No. 13 of 2006 was duly converted again, to make room for the regional head of local government in the Province/District/City, to set a minimum threshold associated with the use of money $U P / G U$, toward direct payments to third parties related goods and services. Presidential Decree number 54 of 2010, has given space to nominal 100 million, related to spending or procurement for the procurement of goods and services directly. Direct procurement is not to see the properties or provide provisions in terms of spending on goods and services, but it belongs to the category of capital expenditures space.
\end{abstract}

Key words: budget, budget users

\begin{abstract}
Abstrak
Penulisan ini bertujuan membahas Kedudukan Pengguna Anggaran dan Kuasa Pengguna Anggaran dan Implikasinya. Tulisan ini menggunakan penelitian yuridis normatif. Hasil dari tulisan ini, Peraturan nomor 21 tahun 2011, atau perubahan ke 2 Peraturan nomor 13 tahun 2006 sepatutnya diubah lagi, untuk memberikan ruang bagi kepala daerah pemerintah daerah di Provinsi/Kabupaten/Kota, untuk menetapkan batas minimum terkait dengan penggunaan uang UP/GU, terhadap pembayaran langsung kepada pihak ketiga barang dan jasa yang terkait. Keputusan Presiden nomor 54 Tahun 2010, telah memberikan ruang sampai nominal 100 juta, terkait belanja atau pengadaan barang dan jasa atas pengadaan langsung. Pengadaan langsung bukan untuk melihat sifat atau memberikan ketentuan didalam hal belanja barang dan jasa, tetapi hal ini termasuk kategori ruang belanja modal.
\end{abstract}

Kata kunci: anggaran, pengguna anggaran

\section{Latar Belakang}

Berbicara mengenai pengertian hukum, hukum dapat diartikan sebagai suatu ilmu pengetahuan, tentang disiplin, tentang kaidah, tentang tata hukum, tentang petugas (penegak hukum didalam penegakan hukum), tentang keputusan penguasa, tentang proses pemerintahan, tentang perilaku atau sikap dari tindakan yang teratur dan tidak menyimpang dari perilaku orang banyak. Didalam bagian norma hukum, hukum memiliki peran yang sangat penting. Norma adalah suatu aturan atau kebiasaan yang tumbuh dan dipakai didalam kehidupan bermasyarakat, sehingga 
makna dari sebuah norma tesebut adalah segala sesuatu aturan yang harus dipakai. ${ }^{1}$

Indonesia menggunkan istilah hukum yang digunakan dalam kehidupan seharihari untuk menunjukkan norma-norma yang berlaku di Indonesia, norma hukum di Indonesia berbentuk tertulis yang terkodifikasi maupun tidak terkodifikasi maupun bentuk-bentuk yang tidak tertulis, sedangkan norma masyarakat itu tumbuh dengan kebiasaan masyarakat yang telah dipakai sejak lama dan kebayakan bentuknya itu tidak tertulis akibat kebiasaaan-kebiasaan yang ada didalam masyarakat. Bentuk aturan hukum yang dibentuk secara tertulis maupun tidak tertulis, oleh lembaga-lembaga yang berwenang membentuknya diwujudkan dalam perundang-undangan.

Berdasarkan tata hierarki pembentukkan peraturan perundang-undangan, menyebutkan bahwa hirarki perundang-undangan Indonesia meliputi: ${ }^{2}$

(1) Posisi pertama ditempati UndangUndang Dasar Negara Kesatuan Republik Indonesia Tahun 1945 menjadi acuan peraturan negara atau sumber hukum tertinggi dan menjadi sumber bagi peraturan perundang-undangan lainnya.

(2) Posisi kedua adalah Ketetapan Majelis Permusyawaratan Rakyat Republik Indonesia (singkatnya TAP-MPR).

(3) Posisi ketiga adalah Undang-Undang atau Peraturan Pemerintah Pengganti Undang-Undang, atau yang lazim disebut Perpu.
(4) Posisisi kempat presiden berhak mengeluarkan Peraturan Pemerintah (singkatnya PP).

(5) Posisis kelima untuk melaksanakan peraturan pemerintah adalah Peraturan Presiden (singakatnya Perpres).

(6) Pada posisi terakhir didalam tata hierarki pemebentukkan peraturan perundangundangan hierarki adalah Peraturan Daerah, atau yang sering disebut Perda. Perda ini meliputi Perda yang dikeluarkan oleh provinsi, Perda yang dikeluarkan oleh kabupaten/kota dan Perda yang dikeluarkan oleh peraturan desa atau peraturan yang setingkat. Adapun wewenang untuk menetapkan Perda berada pada kepala daerah atas persetujuan Dewan Perwakilan Rakyat Daerah.

Dalam peraturan perundang-undangan setiap aturan secara hirarki tidak boleh bertentangan antara peraturan dengan aturan lain. Artinya, setiap jenis peraturan perundang-undangan harus berlandaskan terhadap azas yang menyatakan bahwa peraturan perundang-undangan yang lebih rendah tidak boleh bertentangan dengan peraturan perundang-undangan yang diatasnya. Hal inilah yang disebut hirarki peraturan perundang-undangan.

Berdasarkan penganalisaan penulis, terdapat dua peraturan yang menjadi perbedaan secara leterlijk. Yakni: (1) Peraturan Presiden Nomor 54 Tahun 2010 tentang Pengadaan Barang Dan Jasa Pemerintah (Perpres 54/2010) dan (2) Permendagri

1 Maria Farida Indriati, Ilmu Perundang-undangan, Kanisinus, Yogyakarta, 1998, hlm. 18.

2 Undang-undang Republik Indonesia Nomor 12 Tahun 2011 tentang Tata Urutan Peraturan Perundangundangan. 
Nomor 21 Tahun 2011 tentang Pedoman Pengelolan Keuangan Daerah (Permendagri 21/2011), dua peraturan tersebut memiliki penafsiran yang sangat berbeda. Berdasarkan Permendagri Pasal I point 2 tertulis Diantara Pasal 10 dan Pasal 11 disisipkan 1 (satu) Pasal baru yaitu Pasal 10A, sehingga menjelaskan sebagai berikut, terhadap pengadaan barang atau jasa, Pengguna Anggaran (PA) akan mempunyai tindakai sebagai seorang Pejabat Pembuat Komitmen (PPK) sesuai dengan ketentuan peraturan perundang-undangan di bidang terhadap Pengadaan Barang atau Jasa Pemerintah”. Pasal I point 3, ketentuan Pasal 11 ditambahkan 1 (satu) ayat baru yaitu ayat (5), tertulis dalam pengadaan barang/jasa. "Kuasa Pengguna Anggaran (KPA) sebagaimana dimaksud pada ayat (1), sekaligus bertindak sebagai Pejabat Pembuat Komitmen (PPK)'”. Sesuai dengan pengadaan barang/jasa yang merujuk pada Perpres 54/2010, Pasal 8 ayat (1) huruf c, disebutkan bahwa "Pengguna Anggaran (PA) memiliki tugas dan kewenangan salah satunya adalah menetapkan Pejabat Pembuat Komitmen $(P P K)$ ". Kemudian pada Pasal 12 ayat (1) tertulis: "Pejabat Pembuat Komitmen (PPK) merupakan Pejabat yang ditetapkan oleh PA/ KPA untuk melaksanakan Pengadaan Barang/ Jasa”.

Adanya kata "menetapkan" dan “ditetapkan" pada kedua pasal di atas, berarti
PA/KPA menetapkan orang lain untuk menjadi PPK dan bukan menetapkan dirinya sendiri. Sedangkan di Permendagri 21/2011, PA/KPA secara otomatis menjadi PPK. Padahal secara hirarki dua peraturan ini tidak boleh terjadi, Peraturan menteri dalam negeri secara hirarki yang berada di bawah Presiden, harus sejalan dengan peraturan yang di atasnya yakni Peraturan Presiden.

Secara teoritik, pembahasan tentang bentuk-bentuk peraturan perundangundangan, pada dasarnya tidak dapat dilepaskan dari konsep hierarki norma hukum $^{3}$. Dua aturan yang secara hirarki mestilah harus memiliki sinkronisasi antara peraturan di bawah dengan peraturan di atasnya, agar tidak terjadi kesalahtafsiran terhadap pelaksanaan peraturan tersebut dalam tata kelola pemerintahan dan tidak terjadi kekeliruan dalam melaksanakannya.

Hukummerupakan landasan pembangunan di bidang lainnya yang bermakna teraktualisasinya fungsi hukum sebagai alat rekayasa sosial atau pembangunan (law as a tool of social engineering), instrumen penyelesaian masalah (dispute resolution), dan instrumen pengatur perilaku masyarakat (social control). Begitupun untuk konteks Indonesia, hukum telah memberikan peran penting melalui tiga fungsinya tersebut. ${ }^{4}$

Peraturan Presiden maupun Peraturan Menteri Dalam Negeri dalam meningkatkan

3 Yuliandri, Asas-asas Pembentukan Peraturan Perudang-undangan yang Baik, RajaGrafindo Persada, Jakarta, 2011, hlm. 47.

4 Aziz Syamsuddin, Proses dan Teknik Penyusunan Undang-undang, Sinar Grafika, Jakarta, 2011, hlm. 1. 
efesiensi dan efektifitas penggunaan keuangan Negara yang dibelanjakan melalui Proses Penggadaan Barang/Jasa Pemerintah berguna untuk menciptakan peningkatan kualitas terhadap pelayanan publik melalui penyelenggaraan pemerintahan yang baik dan bersih, maka harus didukung dengan pengelolaan keuangan yang efektif, efesien, transparan, dan akuntabel. Hal ini mestilah berdasarkan aturan yang ada, agar meningkatkan efesiensi serta efektifitas terhadap penggunaan keuangan Negara yang nantinya akan dibelanjakan berdasarkan Proses Penggadaan Barang/Jasa Pemerintah.

Untuk menciptakan keterbukaan, trasparansi, akuntabilitas serta prinsip persaingan/ kompetensi yang sehat dalam proses penggadaan barang/jasa, terutama anggaran belanja Pemerintah Daerah yang dibiayai oleh APBN/APBD, sehingga diperoleh Barang/Jasa yang terjangkau dan berkualitas serta dapat dipertanggungjawabkan baik dari segi fisik, keuangan, maupun untuk kelancaran tugas pemerintah dalam pelayanan masyarakat. Namun, kedua peraturan tersebut secara subtansi terdapat penafsiran leterjik atau harfiah (what does the word mean $)^{5}$ khususnya, pasal 8 dalam Perpres 54/2010 tidak sejalan dengan Permendagri 21/2011 khususnya pasal I point 2 tertulis "Diantara Pasal 10 dan Pasal 11 disisipkan 1 (satu) Pasal baru yaitu Pasal 10A, seperti yang dijelaskan di atas.
Semestinya Permendagri harus merujuk kepada Perpres sebagai aturan tertinggi yang merupakan salah satu peraturan operasional dalam implementasi Otonomi Daerah. Peraturan-peraturan yang dikeluarkan oleh Mendagridalamrangkapembinaan pemerintah daerah masih bersifat pedoman umum yang masih harus ditindaklanjuti dengan peraturan daerah maupun peraturan kepala daerah. Yang lebih penting lagi, adalah peraturan-peraturan tersebut harus sinkron (tidak menyimpang antara satu dengan yang lainnya) dengan peraturan yang lebih tinggi yaitu UndangUndang dan Peraturan Pemerintah.

Permendagri tersebut masih banyak mengandung ketidakjelasan dan ketidaktegasan dalam memberikan pedoman kepada daerah dalam melaksanakan anggaran belanja daerah terhadap barang dan jasa serta aset daerah, terutama tentang Pengguna Anggaran dan Kuasa Pengguna Anggaran dalam dua peraturan tersebut. Hal ini, mengakibatkan kebingungan oleh pemerintah daerah dalam pengelolaan anggaran belanja daerah terhadap barang dan jasa.

Dari latar belakang di atas dapat merumuskan masalah dalam bentuk pertanyaan-pertanyaan sebagai berikut ini.

1. Bagaimanakah kedudukan Pengguna Anggaran dan Kuasa Pengguna Anggaran menurut Permendagri 21/2011?

2. Bagaimanakah implikasi hukum berdasarkan Permendagri 21/2011?

5 Jimly Asshiddiqie, Pengantar Ilmu Hukum Tata Negara, RajaGrafindo Persada, Jakarta, 2010, hlm. 220. 


\section{Pembahasan}

\section{A. Tinjauan Umum Pembentukan Peraturan Perundang-undangan}

Tata urutan perundang-undangan diurutkan secara hirarki, dimana peraturan di bawahnya tidak boleh bertentangan atau mengatur hal selain yang diperintahkan oleh peraturan di atasnya. Hal ini sesuai dengan satu azas hukum, bahwa peraturan perundang-undangan yang lebih rendah tidak boleh bertentangan dengan peraturan perundang-undangan yang diatasnya. Dengan cara seperti itu, dimaksudkan akan adanya tertib administrasi pengaturan perundangundangan yang lebih baik dan tertata untuk menghindari adanya pelampauan wewenang. Sejalan dengan hal di atas Bagir Manan menyatakan, apabila ternyata peraturan perundang-undangan yang lebih rendah tingkatannya bertentangan dengan peraturan perundang-undangan diatasnya, peraturan perundang-undangan tersebut dapat dituntut untuk dibatalkan bahkan batal demi hukum. ${ }^{6}$ Bahwa peraturan lain selain yang disebutkan dalam tata urutan perundang-undangan, kedudukannya didalam hukum tetap diakui dan tetap memiliki kekuatan hukum yang sifatnya mengikat, sepanjang aturan yang lebih tinggi memerintahkannya ${ }^{7}$.

Di dalam bagian penjelasan tata hierarki pembentukkan peraturan perundang- undangan, kita bisa melihat asas dalam materi muatan peraturan perundang-undangan, adapun penjelasan dari asas-asas dalam materi muatan peraturan perundang-undangan adalah sebagai berikut ${ }^{8}$ :

a. Asas Pengayoman

Berfungsi untuk memberikan perlindungan-perlindungan terhadap rangkaian untuk menciptakan ketentraman didalam kehidupan bermasyarakat.

b. Asas berdasarkan Kemanusiaan Harus menjunjung tingginya kemanusian, serta saling menghormati manusia satu sama lain.

c. Asas Kebangsaan

Asas kebangasaan ini adalah cerminan terhadap sifat-safat serta watak dari bangsa Indonesia yang bersifat pluralistic atau yang bisas disebut kebhinekaan, dimana hal ini tetap mengedepankan prinsip-prinsip dari Negara kesatuan Republik Indonesia.

d. Asas berdasarkan Kekeluargaan

Terhada asas ini, sebenarnya merupakan cerminan dari sifat bangsa Indonesia, yang selalu menegdepankan musyawarah untuk mencapai suatu mufakat didalam setiap keputusan yang diambil.

e. Asas berdarkan Kenusantaraan

Didalam asas kenusantaraan, haruslah mengedepankan kepentingan dari seluruh wilayah Indonesia bersumberkan dari Pancasila.

f. Asas Bhinneka Tunggal Ika

Memberikan pengertian bahwa terhadap keragaman penduduk, bahasa, adat, suku, agama, golongan, budaya dan kondisi spesifik suatu daerah tidaklah menjadi penghalang atau masalah-masalah

6 Yuliandri, Op.cit., hlm. 50.

7 Ibid.

8 Aziz Syamsuddin, Op.cit., hlm. 33. 
yang sifatnya sensitif dalam kehidupan bermasyarakat, berbangsa, dan bernegara, hal-hal inilah yang harusnya lebih diperhatikan didalam membentuk materi muatan peraturan perundangundangan.

g. Asas Keadilan

Mencerminkan keadilan secara proposional bagi setiap warga negara tanpa ada pengecualian, karena hal inilah yang nantinya tidak menimbulkan kecemburuan sosial diantara masyarakat.

h. Asas kedudukan yang sama

Dalam pembentukan perundangundangan ini haruslah mencerminkan kedudukan dalam hukum dan pemerintahan yang sama.

i. Asas kepastian hukum dan ketertiban hukum

Materi perundang-undangan harusalah menciptakan kepastian dan ketertiban hukum.

j. Asas keserasian, keselarasan dan keseimbangan

Dalammenciptakan perundang-undangan haruslah sesuai dengan keserasian, keselarasan dan keseimbangan.

Untuk memahami asas-asas pembentukan peraturan perundang-undangan yang baik, dapat dimulai dari pengertian tentang asas hukum. ${ }^{9}$ Paul Scholten menjelaskan bahwa asas hukum bukanlah sebuah aturan-aturan hukum atau nama biasanya rechtsregel, yang nantinya dipakai dan diterapkan didalam masyarakat dan negara hukum. Agar bisa dikatakan sebagai sebuah aturan hukum yang berlaku, sebuah asas hukum harus menjelaskan secara umum, sehingga hal itu sama sekali tidak banyak bicara atau nama lazimnya of niets of veel te veel zeide. Terhdap penerapan-penerapan asas hukum yang sifatnya langsung, harusnya telah melalui tahapan pada tahap subsumsi ataupun dalam tahap pengelompokan-pengelompokan sebagai sesuatu aturan yang sifatnya tidak mungkin, terhadap hal ini harusnya terlebih dahulu perlu dibentuk isi ataupun materi yang sifatnya lebih kongkrit atau nyata.

Didalam asas-asas pembentukan peraturan perundang-undangan yang baik hatuslah berisikan asas hukum yang memberikan pedoman dan bimbingan bagi isi peraturan yang dibentuk nantinya, sehingga sesuai didalam pembentukan dan susunannya, serta tepat didalam penggunaan metodemetodenya, dan tidak lupa mengikuti proses dan prosedur pembentukan sesuai dengan ketentuan yang ada. ${ }^{10}$ Guru besar perundangundangan Prof.A. Hamid S. Attamimi memiliki pendapat, bahwa didalam asas-asas pembentukan peraturan perundang-undangan yang patut, khususnya dalam tatanan kehidupan keindonesiaan, terdiri atas: Citra Hukum Indonesia, Asas Negara Berdasar Hukum dan Asas Pemerintahan Berdasar Sistem Konstitusi, dan asas-asas lainnya. ${ }^{11}$

Dalam pembentukan peraturan perundang-undangan, selain memakai asasasas pembentukan perundang-undangan yang sesuai dengan aturan yang baik, juga harus
9 Ibid., hlm. 19.

10 Ibid., hlm. 23.

11 Maria Farida Indriati, Op.cit., hlm. 196-197. 
berlandaskan kepada asas-asas hukum umum, asas hukum umum ini terdiri atas asas hukum Negara berdasar atas hukum atau yang sering orang hukum sebut Rechstaat, asas hukum umum pemerintahan berdasarakan sistem konstitusi,dan terakhir berdasarkan asas hukum Negara yang berlandaskan etrhadap kedaulatan rakyat.

Menurut Bagir Manan, agar terciptanya sebuah undang-undang yang tangguh dan berkualitas, dapat digunakan beberapa landasan dalam menyusun undang-undang, yaitu: ${ }^{12}$

a. Landasan Filosofis

Undang-undang harus mengandung norma-norma hukum yang ideal (ideal norms) oleh suatu kumpulan masyarakat ke arah mana cita-cita luhur kehidupan bermasyarakat bernegara hendak diarahkan.

b. Landasan Sosiologis

Setiap norma hukum yang akan dituangkan dalam bentuk suatu undangundang, cerminan undang-undang tersebut haruslah berdasarkan tuntutan kebutuhan masyarakat sendiri akan norma hukum yang sesuai dengan realita kesadaran hukum masyarakat.

c. Landasan Yuridis

Landasan yuridis merupakan landasan pembentukan peraturan perundangundangan yang menjadi legitimasi atau keabsahan dari suatu peraturan perundang-undangan. Landasan yuridis harus memuat empat prinsip, yaitu:

(1) Prinsip negara hukum yaitu prinsip yang harus dijadikan pegangan dalam pembentukan peraturan perundang-undangan, dimana setiap peraturan perundangundangan harus sesuai dengan peraturan perundang-undangan yang lebih tinggi.

(2) Konstitusionalitas

Pembentukan peraturan perundangundangan harus sesuai dengan konstitusi atau undang-undang dasar, karena konstitusi merupakan induk dari segala peraturan perundangundangan.

(3) Prinsip Demokrasi

Hal ini menjelaskan bahwa didalam pembentukan peraturan perundangundangan harus memilik sifat secara transparasi atau terbuka, dimana harus adanya partisipasi rakyat dalam pembentukan peraturan perundangundangan tersebut.

(4) Prinsip perlindungan terhadap hak-hak rakyat

Hal ini menjelasakan bahwa pembentukan peraturan perundangundangan harus melindungi dan menjamin hak-hak rakyat.

Agar terciptanya suatu produk perundangundangan yang baik dalam substansi nya maupun secara prosedural dan sesuai berdasarkan tata urutan perundang-undangan secara hirarki yang dijelaskan diatas, maka diperlukan beberapa asas dalam membentuk peraturan perundang-undangan tersebut, yaitu dengan adanya kejelasan tujuan, adanya kejelasan kelembagaan atau organ pembentukan yang tepat, memiliki kesesuaian antara jenis dan materi muatan, serta dapat dilaksanakan, memiliki kedayagunaan dan kehasilgunaan, adanya kejelasan rumusan, dan serta memilki keterbukaan atau transparansi.

a. Kejelasan Tujuan.

Yang dimaksud dengan kejelasan tujuan 
menjelaskan bahwa, didalam membentuk sebuah peraturan perundang-undangan, nantinya haruslah mempunyai sebuah tujuan yang jelas hendak untuk dicapai.

b. Tepatnya lembaga atau organ

Harus tepatnya organ atau lembaga negara yang membentuk undang-undang, sesuai dengan ketentuan yang ada.

c. Jenis dan materi muatan yang sesuai.

Harus sesuainya undang-undang tersebut dengan jenis dan materi muatan, sesuai dengan aturan yang ada.

d. Dapat dilaksanakan.

Yang dimaksud dengan asas dapat dilaksanakan adalah bahwa pembentukan peraturan perundang-undangan, haruslah memperhitungkan terhadap kegunaan dan fungsi peraturan perundangundangan tersebut di dalam kehidupan masyarakat, baik secara yuridis, filosofis, maupun sosiologis.

e. Kedayagunaan dan kehasilgunaan. Yangdimaksuddenganasaskedayagunaan dan kehasilgunaan peraturan menjelaskan bahwa perundang-undangan yang dibuat,memang benar-benar akibat dari kebutuhan yang memilik manfaat untuk mengatur seluruh lapisan kehidupan didalam bermasyarakat, didalam berbangsa, dan didalam bernegara.

f. Rumusan yang jelas.

Harus adanya rumusan yang jelas didalam peraturan perundang-undangan tersebut, atau sesuai dengan ketentuan yang berlaku. g. Adanya Keterbukaan.

Harus adanya sifat keterbukaan atau tranpasransi didalam pembentukkan perundang-undangan. Serta dituntu peran serta masyarakat.

Menurut Ruiter, norma yang ada di dalam peraturan perundang-undangan yang dibentuk dapat mengandung dari salah satu sifat-sifat sebagai berikut ini: 1) perintah (gebod); 2) larangan (verbod); 3) pengizinan (toestemming); dan 4) pembebasan (vrijstelling). Dalam Pasal 10 UU 12/2011, ada hal di dalam materi-materi terhadap muatan yang harusnya telah diatur sesuai dengan ketentuan undang-undang yang berlaku, antara lain akan dijlaskan dibawah ini:

a. Undang-undang Dasar Negara Republik Indonesia Tahun 1945 merupakan dasar ketentuannya.

b. Perintah terhadap suatu Undang-undang yang nantinya diatur dengan Undangundang.

c. Pengesahan perjanjian Internasional tertentu.

d. Tindak lanjut atas keputusan Mahkamah Konstitusi.

e. Pemenuhan kebutuhan hukum dalam masyarakat.

Didalampasal11UU12/2011merumuskan, adanya materi muatan Perpu yang sama dengan materi muatan Undang-Undang tersebut. Kemudian pasal 12 menjelasakan mengenai materi muatan PP yang berisikan materimateri untuk menjalankan Undang-Undang sesuai dengan semestinya. Kemudian pasal 13 
menjelasakan hal-hal terhadap materi muatan Perpres, yang berisikan mengenai materimateri terhadap melaksanakan PP, atau materi untuk melaksanakan kepada penyelenggaraan terhadap kekuasaan pemerintahan, materimateri ini lansung akan diperintahkan oleh Undang-Undang. Sedangkan di pasal 14 materi muatan Peraturan Daerah Provinsi dan Peraturan Daerah Kabupaten/Kota berisikan materi muatan dan substansi-substansi, yang berkaitan lansung didalam rangka penyelenggaraan otonomi daerah serta tugas pembantuan dan juga menampung kondisi khusus daerah atau penjabaran lebih lanjut Peraturan Perundang-undangan yang berada diatasnya.

\section{B. Kedudukan Pengguna Anggaran dan Kuasa Pengguna Anggaran Menurut Permendagri 21 Tahun 2011}

Anggaran pendapatan merupakan alat perencanaan untuk mengindikasikan target yang harus dicapai oleh pemerintah, sedangkan anggaran belanja sebagai alat pengendalian mengindikasiakan alokasi sumber dana publik yang disetujui legislatif untuk dibelanjakan. Dalam Proses penyusunan Anggaran Pendapatan dan Belanja Daerah (APBD) melibatkan partisipasi banyak pihak, serta membutuhkan pertimbangan-pertimbangan teknis akuntansi yang matang. Antara lain, dalam penyusunan APBD yakni akuntansi pemerintahan dibutuhkan terutama untuk mengestimasi biaya program dan kegiatan, serta memprediksi kondisi ekonomi pemerintah daerah berikut perubahanperubahan yang akan terjadi.

Anggaran Pendapatan dan Belanja Daerah (APBD), adalah rencana keuangan tahunan pemerintah daerah di Indonesia yang disetujui oleh Dewan Perwakilan Rakyat Daerah (DPRD). Dalam penetapan APBD dilakukan dengan Peraturan Daerah. Masa satu tahun, mulai dari tanggal 1 Januari sampai dengan tanggal 31 Desember, meruapakan tahun anggaran dari sebuah APBD. DPRD memiliki kewenangan untuk ikut menentukan arah dan kebijakan umum APBD. Apabila DPRD didalam tahap perencanaan (baca: kebijakan umum APBD dan penentuan arah) sifatnya lemah, maka akan sangat dikhawatirkan pada tahap pelaksanaannya nanti, mengalami banyak penyimpangan. ${ }^{13}$

Adapun fungsi-fungsi dari anggaran pendapatan dan belanja daerah, akan dijelaskan sebagai berikut: ${ }^{14}$

1. Terhadap fungsi otorisasi mempunyai makna bahwa anggaran daerah merupakan dasar untuk merealisasi pendapatan dan belanja daerah pada tahun yang bersangkutan. Tanpa adanya penganggaran didalam APBD, maka sebuah kegiatan tidak akan memiliki

13 Chabib Soleh dan Heru Rochmansjah, Pengelolaan Keuangan dan Aset Daerah, Fokus Media, Jakarta, 2010, hlm. 125 .

14 Wikipedia, Anggaran Pendapatan dan Belanja Daerah, http://id.wikipedia.org/wiki/Anggaran_Pendapatan_ dan Belanja Daerah, diakses 27 Mei 2015 pukul 19.10 WIB. 
kekuatan untuk pelaksanakannya.

2. Terhadap fungsi perencanaan memilik makna bahwa sebuah anggaran daerah menjadi acuan terhadap manajemen didalam merencanakan kegiatan-kegiatan pada tahun yang bersangkutan.

3. Terhadap fungsi pengawasan memiliki makna bahwa sebuah anggaran daerah akan menjadi acuan didalam menilai sebuah keberhasilan atau kegagalan didalam proses penyelenggaraan sebuah pemerintah daerah.

4. Terhadap fungsi alokasi memberikan makna bahwa sebuah anggaran daerah haruslah diarahkan kepada usaha untuk menciptakan sarana lapangan kerja, yang nantinya berguna untuk mengurangi pengangguran, dan pemborosan akan sumberdaya alam dan manusai, serta dalam taraf meningkatkan efisiensi dan efektifitas perekonomian sebuah daerah.

5. Terhadap fungsi distribusi memberikan makna atau artian bahwa didalam pemeberian kebijakan sebuah penganggaran daerah, pemerintah haruslah memperhatikan faktor rasa keadilan dan kepatutan.

6. Terhadap fungsi stabilitasi memberikan makna bahwa setiap anggaran daerah, haruslah menjadi sebuah alat didalam memelihara dan mengupayakan setiap keseimbangan fundamental perekonomian sebuah daerah.

Prinsip-prinsip terhadap Penyusunan Anggaran Pendapatan dan Belanja Daerah
(APBD) disajikan sebagai berikut:

1. Komprehensif dan disiplin.

Anggaran daerah harus disusun secara komprehensif, dan disiplin, agar menciptakan penyusunan anggaran daerah yang ideal.

2. Fleksibilitas.

Didalam penyusunan anggaran daerah ini haruslah berdasarkan fleksibilitas, terutama arahan dari pusat kepada daerah, tetapi hal ini tidak akan mematikan inisiatif dari daerah dan prakarsa dari daerah.

3. Terprediksi.

Memberikan penjelasan bahwa kebijakan yang terprediksi ini adalah faktor yang sangat penting didalam peningkatan kualitas implementasi dari anggaran daerah. Sebaliknya, bila ada kebijakan yang sering berubah-ubah, seperti metode pengalokasian Dana Alokasi Umum (DAU) yang tidak jelas mekanismenya.

4. Kejujuran.

Kejujuran ini juga harus menyangkut keberadaan terhadap penerimaan dan pengeluaran.

5. Informasi.

Informasi adalah hal yang paling utama, terutama kejujuran dan proses pengambilan keputusan yang baik. Pelaporan yang teratur tentang biaya output, dan dampak suatu kebijakan sangatlah penting.

6. Transparansi dan Akuntabilitas.

Mejelasakan bahwa transparansi 
masyarakat haruslah sebagai perumusan kebijakan yang memiliki pengetahuan tentang permasalahan dan informasi yang sesuai sebelum kebijakan-kebijakan dijalankan. Selanjutnya, akuntabilitas memberikan isyarat bahwa pengambilan keputusan haruslah berprilaku sesuai dengan mandat yang akan diterimanya. Perumusan dari kebijakan ini akan secara bersama-sama, digunakan untuk mencapai metode dan hasil dari kebijakan tersebut, sehinggan hal ini nantinya bisa diakses oleh semua orang dan bisa dikomunikasikan secara vertikal serta horizontal didalam setiap golongan masyarakat. Hal ini akan memberikan efek yang positif didalam tranparansi dan akuntabilitas tersebut.

Khusus terhadap pelaksanaan APBD yang terkait dengan Belanja Barang/Jasa yang dilaksanakan oleh Pengguna Anggaran (PA) atau Kuasa Pengguna Anggaran (KPA) pada Satuan Kerja Perangkat Daerah (SKPD), yang dalam pelaksanaan diatur menurut Pepres 54/2010 dan Permendagri 21/2011. Dalam pelaksaan belanja barang/jasa tersebut dilaksanakan secara organisasi, yang terdiri dari:

1. Menurut Pepres 54/2010, struktur organisasi pelaksanaan belanja barang/ jasa, sebagai berikut: PA; KPA dan PPK (Pejabat Pembuat Komitmen)

2. Menurut Permendagri 21/2011, struktur organisasi pelaksanaan belanja barang/ jasa, sebagai berikut: PA/KPA dan PPTK
Pengguna Anggaran yang selanjutnya (PA) adalah adalah pejabat yang memegang terhadap kewenangan penggunaan anggaran untuk melaksanakan tugas pokok dan fungsi anggaran Kementrian, Lembaga, Satuan Kerja Perangkat Daerah (SKPD) yang dipimpinnya atau Pejabat yang disamakan pada Institusi lain pengguna APBN/APBD.

\section{Kedudukan PA dalam pengadaan barang/jasa}

Mendefinisikan PA berdasarkan Pasal 1 Angka 5 Perpres 54/2010, adalah Pejabat yang memegang kewenangan terhadap penggunaan anggaran-angaran Kementerian, Lembaga, maupun Satuan Kerja Perangkat Daerah (SKPD) atau Pejabat yang disamakan pada institusi lain terhadap penggunaan APBN atau APBD. Hal ini mengacu berdasarkan Pasal 1 angka 12 UU 1/2004, dan konsiderans Perpres UU 1 /2004. Siapa saja yang dapat menjadi PA didalam Perpres tersebut tidak disebutkan dengan jelas, sehingga didalam menentukan yang dapat menjadi PA, haruslah mengacu pada UU 1/2004. Pemegang PA akan dijelaskan sebagai berikut, yaitu:

a. Pemegang PA haruslah/merupakan Menteri/pimpinan lembaga yang memimpin kelembagannya tersebut.

b. pemegang PA haruslah/merupakan seorang Gubernur bagi Pemerintah Provinsi, Bupati bagi Pemerintahan Kabupaten atau Walikota bagi Pemerintahan Kota, selaku pemipmin dari Pemerintah Daerah tersebut;

c. Pemegang PA adalah seorang yang 
mengepalai SKPD bagi SKPD yang dikepalainya atau yang dikelolalnya.

\section{Kedudukan KPA di dalam pengadaan barang atau jasa}

Ketentuan dari Pasal 1 Angka 6 Perpres 54/2010 memberikan penjelasan bahwa Kuasa Pengguna Anggaran terhadap pejabat yang telah ditetapkan oleh PA, didalam penggunaan APBN atau hal yang telah ditetapkan oleh seoarang Kepala Daerah didalam penggunaan APBD.

Terhadap definisi PA yang telah dijelaskan diatas, maka definisi KPA tersebut mengacu kepada definisi KPA didalam ketentuan pasal 1 angka 18 UU 1/2004. Siapa yang menjabat atau menjadi KPA tersebut tidak ada pengaturannya, hal ini merupakan akibat dari mengingat, definisi dari KPA tersebut adalah pemegang kuasa dari Pengguna Anggaran. Penetapannya tersebut, akibat dari pelimpahan wewenang berupa pemberian kuasa, maka terhadap penetapan PA sebagai KPA, haruslah dengan beberapa pertimbangan tertentu.

Pemilihan terhadap siapa saja yang nantinya akan ditetapkan sebagai KPA yang bertanggunga jawab, dan menjadi acuan dasarnya haruslah melihat pada kewewenangan dari PA tersebut. Menurut analisis penulis, khususnya untuk seseorang yang akan menjadi Kepala Unit Kerja pada SKPD yang berimplikasi akan ditetapkan menjadi KPA nantinya oleh Kepala Daerah, Kepala Daerah haruslah mengusulkan Pengguna Anggaran tersebut ${ }^{15}$, acuannya menurut penulis berdasarkan pasal 11 ayat (2) PP 58/2005 serta penjelasan pasal 5 UU $1 / 2004$.

Melihat kedudukan KPA haruslah sebagai aparatur didalam menjalankan kuasa, sehingga terhadap kewenangan KPA ini, hanya terbatas khusus berdasarkan pada pelimpahanpelimpahan terhadap kewenangan yang diberikan, dengan demikian, jelas bisa dilihat ketika KPA ditetapkan didalam pengadaan barang/jasa, maka kewenangannya pun sejalan dengan kewenangan PA sebagaimana yang telah diatur didalam Perpres 54/2010. KPA bukanlah sebagai sebuah jabatan (baik jabatan secara struktural maupun fungsional), sehingga didalam pertimbangan terhadap pemilihan aparatur yang akan ditetapkan sebagai KPA, tidaklah melihatnya apakah KPA terikat menjadi seoarang pejabat struktural ataupun pejabat fungsional. Sebagaimana yang telah disebutkan didalam ketentuan pasal 11 ayat (3) PP 58/2005, pertimbangan yang baik itu adalah pertimbangan dapat dilihat pada tingkatan daerah, besaran dari jumlah SKPD, besaran jumlah banyaknya uang yang telah dikelola, beban-beban kerja, lokasi atau tempatnya, serta dilihat dari kompetensi dan/atau rentang kendali dan pertimbangan objektif-objektif lainnya. 


\section{Implikasi Hukum \\ Permendagri 21/2011}

Keuangan pemerintah daerah merupakan faktor yang sangat menentukan dalam penyelenggaraan pemerintah daerah. ${ }^{16}$ Kemampuan keuangan daerah ditentukan oleh adanya sumber pendapatan daerah dan tingkat lukratifnya. Tingkat lukratif sumber pendapatan daerah ditentukan oleh sejauh mana dasar pendapatan daerah ditentukan dari dari sejauh mana dasar pengenaan pajak responsive terhadap inflasi, pertumbuhan penduduk, dan pertumbuhan ekonomi.

Sumber keuangan daerah selalu terkait dengan hubungan keuangan antara pemerintah pusat dengan pemerintah daerah. Dalam hal ini, daerah harus mampu menyelenggarakan kewenangan yang dimiliki, maka dari itu harus ada perimbangan keuangan yang adil dan transparan antara pusat dan daerah. Hubungan antara keuangan pusat dan daerah merupakan cermin dari cara pandang suatu Negara terhadap pemerintah daerahnya.

Acuan didalam pelaksanaan anggaran Negara/Daerah harus berdasarakan pada suatu keputusan Presiden ataupun berdasarkan keputusan Pejabat Daerah yang berwenang. Pelaksanaan anggaran merupakan realisasi atas angka-angka atau sebuah rencana yang telah dicantumkan didalam APBN ataupun APBD, terhadap hal ini pelaksanaannya dapat dibagi atas Pendapatan dan Belanja (Pengeluaran). Pelaksanaan anggaran yang dimulai 1 (satu) Januari tahun yang bersangkutan, sisa anggaran tahun yang lalu 1(satu) tahun sebelumnya menjadi acuan didalam penerimaan awal tahun berjalan.

Dalam penganggaran daerah terdapat juga tiga analisis yang saling terkait, yaitu: ${ }^{17}$

(1) Analisis penerimaan Yaitu analisis mengenai kemampuan daerah dalam menggali sumbersumber pendapatan yang potensial dan biaya-biaya yang dikeluarkan untuk meningkatkan pendapatan tersebut.

(2) Analisis pengeluaran Yaitu analisis mengenaiseberapa besarnya biaya-biaya dari suatu pelayanan publik dari faktor-faktor yang menyebabkan biaya-biaya tersebut meningkat.

(3) Analisis anggaran

Yaitu analisis mengenai hubungan antara pendapatan dan pengeluaran serta kecenderungan yang diproyeksikan untuk masa depan.

Sesuai dengan tugas dan fungsi seorang Menteri menurut Pasal 17 Undang Undang Dasar Negara Republik Indonesia Tahun 1945, maka fungsi dari Peraturan Menteri akan dijelaskan dibawah ini: ${ }^{18}$

a. Penyelenggaraan berdasarkan fungsi ketentuan Pasal 17 Ayat (1) UUD 1945 (Perubahan) dan kebiasaan-kebiasan yang telah ada.

b. Peraturan Presiden yang telah keluar akan lebih lanjut diselenggarakan oleh menteri. Oleh karena fungsi Peraturan menteri disini sifatnya delegasian dari

16 Hanif Nurcholis, Teori dan Praktik Pemerintahan dan Otonomi Daerah, RajaGrafindo, Jakarta, 2005, hlm. 92.

17 Ibid., hlm. 93.

18 Ni'matul Huda dan R. Nazriyah, Teori dan Pengujian Peraturan Perundang-undangan, Nusa Media, Bandung, 2011, hlm. 118. 
Peraturan Presiden, maka Peraturan Menteri disini sifatnya adalah pengaturan lebih lanjut dari kebijakan yang oleh Presiden dituangkan dalam Peraturan Presiden.

c. Berdasakan lanjutan dari ketentuan dalam Undang-Undang yang dengan tegas telah menyebutnya.

d. Berdasarkan Peraturan Pemerintah yang jelas-jelas telah menyebutkannya.

Dalam konsiderans Permendagri 21/2011, ada beberapa alasan-alasan yang menjadi pertimbangan didalam penyusunan, salah satunya penegasan terhadap kedudukan sebagai pejabat pembuat komitmen tersebut. Pasal 10 A juga menerangkan, terhadap pengadaan barang/jasa, PA mempunyai kedudukan sebagai Pejabat Pembuat Komitmen, hal ini berdasarkan pada ketentuan dari peraturan perundang-undangan di bidang Pengadaan Barang/Jasa Pemerintah yang berlaku.

Ketentuan Pasal 11 juga menjelaskan, bahwa terhadap pejabat pengguna anggaran/ pengguna barang, didalam melaksanakan tugas-tugas tersebut, sebagaimana dimaksud dalam Pasal 10, melimpahkan kewenangannya sebagian, kewenagan ini bisa diberikan kepada pimpinan unit kerja pada SKPD, dimana hal ini merupakan selaku kuasa pengguna anggaran atau kuasa pengguna dari barang. Lebih lanjut terhadap pelimpahan sebagian kewenangan tersebut haruslah berdasarkan pertimbangan tingkatan daerah, besaran SKPD, besaran jumlah uang yang dikelola, terhadap beban kerja, terhadap lokasi, terhadap kompetensi, terhadap rentang kendali, dan/atau terhadap pertimbangan-pertimbangan objektif lainnya. Dalam hal pelimpahan sebagian kewenangan sebagaimana dimaksud diatas akan ditetapkan oleh kepala daerah atas usul kepala SKPD. Lebih lanjut terhadap pelimpahan sebagian kewenangan ini, sebagaimana yang dimaksud pada penjelasan tersebut akan meliputi berdasarkan ketentuan dalam pasal ini.

Terhadap Kuasa pengguna anggaran atau kuasa barangyang akan digunaka, sebagaimana dengan maksud tujuan yang diatas, maka pihak yang akan bertanggungjawab terhadap pelaksanaan tugas ini kepada pengguna anggaran atau pengguna barang, dan dialam pengadaan barang atau jasa, terhadap kuasa pengguna anggaran akan sekaligus bertindak sebagai pejabat yang berwenang membuat komitmen.

Berdasarkan penjelasan dari aturan Peraturan menteri dalam negeri 21/2011, maka dapat penulis menyimpulkan bahwa terhadap pengadaan barang/jasa, PA/KPA dapat juga bertindak sebagai PPK. Tidak ada pengaturan hukum yang jelas disebutkan sehingga yang menjadi acuan/patokan adalah aturan Permendagri saja.

Pengaturan pengadaan barang/jasa berdasarkan Perpres 54/2010, memberikan penjelasan bahwa antara PA/PPK dengan PPK 
adanya pemisahan ${ }^{19}$, sehingga jelas terlihat bahwa ada pemberian kewenangan dari PA/ KPA kepada PPK, khususnya didalam hal pengadaan-pengadaan barang/jasa. Pemberian kewenangan terhadap kepada PPK ini, akan menjelasan bahwa kedudukan PPK hanyalah bertanggung jawab kepada PA/KPA.

Ketentuan pasal 12 ayat (2) Perpres 54/2010 memberikan pengertian bahwa PPK adalah pejabat yang bertanggung jawab atas pelaksanaan pengadaan barang atau jasa dan syarat untuk menjadi PPK cukup tinggi. Titik berat dalam Perpres adalah PPK haruslah berasal dari seorang yang profesional dan tidak ada memiliki keberpihakan (independen) sehingga nantinya dapat menjamin adanya interaksi-interaksi ekonomi dan sosial antara berbagai para pihak yang terkait (stakeholders) secara tujuan yang adil, adanya transparansi, profesionalisme, dan serta akuntabel. Berdasarakan hal tersebut Perpres 54/2010 menegaskan akan adanya pemisahan terhadap PA/KPA dengan PPK, sedangkan Permendagri 21/2011 tidak memisahkan jika terjadi pertentangan/konflik terhadap norma hukum, jika ada pertentangan hukum, maka pertentangan tersebut akan dikembalikan kepada tata peraturan perundang-undangan yang berlaku di Indonesia.

Pasal 5 UU 12/2011 menyatakan bahwa ketetuan pembentukan Peraturan Perundangundangan yang baik haruslah berdasarkan pada asas-asas yang dijelasakan dibawah ini, yang meliputi:

a. Asas terhadap adanya kejelasan tujuan;

b. Asas terhadap adanya kelembagaan atau pejabat pembentuk yang tepat;

c. Asas terhadap adanya kesesuaian antara jenis, hierarki, dan materi muatan;

d. Asas terhadap adanya dapat dilaksanakan;

e. Asas terhadap adanya kedayagunaan dan kehasilgunaan;

f. Asas terhadap adanya kejelasan rumusan; dan

g. Asas terhadap adanya keterbukaan.

Kemudian di dalam Pasal 8, jenis Peraturan Perundang-undangan selain sebagaimana dimaksud dalam Pasal 7 ayat (1), juga mencakup peraturan- peraturan yang ditetapkan oleh lembaga-lembaga yang terkait $^{20}$. Penjelasan terhadap ketentuan Pasal 8 ayat (1) adalah, memberikan pengertian

19 Penulis berpendapat bahwa hal ini memberikan pengertian bahwa PA/KPA menetapkan PPK. Sebagaimana yang telah disebutkan didalam konsiderans, bahwa didalam penggunaan keuangan negara yang akan dibelanjakan melalui proses-proses terhadap Pengadaan Barang/Jasa Pemerintah, dimana dtuntut harus bekerja secara efisiensi dan efektif, yang berdampak diperlukannya upaya-upaya yang nanti untuk menciptakan terhadap keterbukaan, terhadap transparansi, terhadap akuntabilitas serta terhadap prinsip persaingan/ kompetisi yang sehat didalam proses-proses Pengadaan Barang/Jasa Pemerintah, yang nantinya dibiayai oleh APBN ataupun APBD. Maka hal ini bertujuan agar diperoleh barang/jasa yang terjangkau dan berkualitas serta dapat dipertanggung-jawabkan nantinya, baik itu dari segi fisik, keuangan, ataupun manfaatnya bagi kelancaran tugas-tugas pemerintah danterhadap pelayanan masyarakat. Hal ini akan menimbulkan efek yang positif didalam penggunaan anggaran.

20 Lembaga-lembaga yang terkait dalam hal ini antara lain: Majelis Permusyawaratan Rakyat (MPR), Dewan Perwakilan Rakyat (DPR0, Dewan Perwakilan Daerah (DPD), Mahkamah Agung (MA), Mahkamah Konstitusi (MK), Badan Pemeriksa Keuangan (BPK), Komisi Yudisial (KY), Bank Indonesia (BI), Menteri-menteri, badan ataupun lembaga-lembaga, atau komisi yang berada setingkat dengan itu. 
bahwa Peraturan Menteri atau lazimnya permen adalah peraturan yang ditetapkan oleh menteri berdasarkan materi muatan dalam rangka penyelenggaraan urusan tertentu di dalam pemerintahan.

Dengan meninjau UU 12/2011, penulis menyimpulkan bahwa permen juga merupakan bagian dari hierarrki Peraturan Perundangundangan yang berlaku, namun menurut penulis seharusnya di dalam pembentukan peraturan menteri tersebut, ada baiknya kalau melihat pada kesesuaian antara jenis, hierarki, dan materi muatan, yang nantinya disusun didalam rangka penyelenggaraan urusanurusan tertentu dalam pemerintahan, sesuai dengan ketentuan pasal 5.

Lebih jauh, terhadap pengaturan PA/KPA yang dapat bertindak sebagai PPK yang telah dinyatakan didalam Permendagri 21/2011, sepertinya menurut penulis hal ini tidak sesuai secara hierarki dan materi muatan dengan Perpres 54/2010. Karena perpres lebih tinggi hierarkinya didalam peraturan perundangundangan yang telah dijelaskan sebelumnya, dibandingkan dengan permendagri. Sesuai dengan asas hukum dari "Lex Superior Derogat Legi Inferiori ${ }^{\text {"21 }}$.

Permendagri No. 21 Tahun 2011 didalam ruang lingkupnya secara luas adalah urusan- urusan tertentu didalam Kementerian Dalam Negeri, seharusnya ruang lingkup ini pengaturan-pengaturan itu harusnya dibaca lebih khusus dan diberlakukan terhadap Kementerian Dalam Negeri. ${ }^{22}$

Dengan terbitnya Permendagri 21/2011 atau perubahan ke 2 atas Permendagri Nomor 13 Tahun 2006, setidaknya memberi kejelasan terhadap beberapa point terkait dengan proses Pengadaan Barang dan Jasa Perpres Nomor 54 Tahun 2010, pada tingkatan level Pemda Provinsi, Kabupaten, kota yang pendanaannya melalui APBD.

Namun ada beberapa pasal pada Permendagri 13/2006 yang perlu untuk diteliti lebih dalam dan diubah atau berdasarkan hal ini telah luput dari pantauan pemerintah, sebelum terbitnyanya Permendagri 21/2011 yakni berdasarkan ketentuan Pasal 206.

Menurut penulis, pada pasal ini pemerintah pusat belum memberikan kewenangan didalam hal menetapkan batasan minimal (thershold), dalam hal penggunaan uang UP/ GU, untuk pembayaran langsung kepada pihak ketiga terkait belanja barang dan jasa, kepada kepala daerah pada Pemda Provinsi, Kabupaten, Kota.

Menurut penulis ada beberapa kejanggalan jika merujuk kepada pengertiaan belanja

21 Peter Mahmud Marzuki, Pengantar Ilmu Hukum, Kencana Prenada Media Group, Jakarta, 2008, hlm. 24.

22 Menurut penulis hal ini sesuai dengan pernyataan Peter Mahmud Marzuki bahwa kekhususan hal tersebut seharusnya bersifat mengatur kea rah yang lebih jauh dan tidak boleh membuat aturan-aturan yang menyimpangi ataaupun bertentangan dengan peraturan-peraturan yang berada di atasnya secara hierarki. Memaknai asas preferensi hukum terebut mengatur tentang aturan yang lebih khusus, namun terhadap asas-asas tersebut tidak dapat meneerapkan dalam hal-hal tersebut, karena kriterianya bisa kita jelasakan apabila terhadap 2 (dua) peraturan tersebut didalam urutan-urutan yang sama atau sejajar didalam hierarki perundang-undangan serta mengatur terhadap hal yang sama, Ibid. 
barang dan jasa pada Permendagri 13/2006 dan perubahannya (Permendagri 21/2011) ${ }^{23}$. Serta belanja modal pada Permendagri $13 / 2006^{24}$, menurut penulis persoalannya adalah pengadaan barang dan jasa yang pijakannya pada Peraturan Presiden Nomor 54/2011, tidak melihat apakah pengadaan barang dan jasa yang dilakukan oleh Program Kerja Unit Layanan Pengadaan tersebut nilai dan manfaatnya ternyata kurang dari 12 (dua belas) bulan saja, tetapi juga melihat pengadaan barang dan jasa tersebut, yang nilai dan manfaatnya lebih dari 12 (dua belas) bulan terhadap belanja modal.

\section{Simpulan}

Berdasarkan hasil pembahasan yang telah dikemukakan oleh penulis sebelumnya, maka dapat ditarik kesimpulan sebagai berikut:

Khusus terhadap pelaksanaan APBD yang terkait dengan Belanja Barang/Jasa yang dilaksanakan oleh PA atau KPA pada SKPD, yang dalam pelaksanaan diatur menurut Pepres 54/2010 dan Permendagri 21/2011. Permendagri 21/2011. atau perubahan ke
2 atas Permendagri 13/2006 sepatutnya harus dirubah lagi dengan memberi ruang kepada kepala daerah pada pemda Provinsi, Kabupaten, Kota untuk dapat menetapkan sendiri penggunaan uang pembayaran langsung terkait barang dan jasa. Dikarenakan pada Perpres 54/2010 memberikan ruang sampai dengan nominal 100 juta terkait pengadaan barang dan jasa dapat dilakukan dengan Pengadaan Langsung, dan pengadaan langsung tersebut termasuk ruang kategori Belanja Modal. Ketika ada ruang kepada kepala daerah untuk menetapkan batasan minimal penggunaan uang terhadap pembayaran langsung terkait barang dan jasa atau terhadap pengadaan barang dan jasa, maka pengadaan barang dan jasa s/d 100 juta dengan metode Pengadaan Langsung, penulis lebih memilih membeli langsung atau sesuai dengan ketentuan lain yang ada didalam mekanisme Perpres 54/2010. Maka disini kita bisa melihat besaran serta jumlah dana ataupun yang telah dibelanjakan, berdasarkan ketersediaan untuk melakukan pengadaan barang dan jasa haruslah sebanding dengan harga serta kualitasnya.

23 Pengertiaan terhadap belanja barang adalah Belanja barang/jasa sebagaimana yang telah dimaksud dalam Pasal 50 huruf $b$, yang nantinya digunakan didalam untuk menganggarkan pengadaan barang-barang dan jasa yang nilai atapun manfaatnya kurang dari 12 (duabelas) bulan, didalam melaksanakan program-program dan kegiatan-kegiatan pemerintahan daerah, termasuk terhadap barang-barang yang nantinya akan diserahkan atau dijual kepada masyarakat atau pihak ketiga nantinya.

24 Pengertian belanja modal adalah Belanja modal sebagaimana yang telah dimaksudkan dalam Pasal 50 huruf c akan digunakan untuk pengeluaran-pengeluaran yang akan dilakukan didalam rangka-rangka pembelian/ pengadaan ataupun pembangunan-pembangunan terhadap aset tetap berwujud, yang mempunyai nilai-nilai manfaat lebih dari 12 (duabelas) bulan yang nantinya akan digunakan dalam kegiatan-kegiatan pemerintahan, contohnya dalam bentuk tanah, dalam bentuk peralatan dan dalam bentuk mesin, bentuk gedung dan bentuk bangunan, bentuk jalan, bentuk irigasi dan bentuk jaringan, serta aset tetap lainnya. 


\section{DAFTAR PUSTAKA}

Buku

Aziz Syamsuddin, 2011, Proses dan Teknik

Penyusunan Undang-undang, Sinar Grafika, Jakarta.

Chabib Soleh dan Heru Rochmansjah, 2010,

Pengelolaan Keuangan dan Aset

Daerah, Fokus Media, Jakarta.

Hanif Nurcholis, 2005, Teori dan Praktik

Pemerintahan dan Otonomi Daerah, RajaGrafindo, Jakarta.

Jimly Asshiddiqie, 2010, Pengantar Ilmu

Hukum Tata Negara, RajaGrafindo Persada, Jakarta.

Maria Farida Indriati, 1998, Ilmu Perundang-

undangan, Kanisinus, Yogyakarta.

Ni'matul Huda dan R. Nazriyah, 2011,

Teori dan Pengujian Peraturan

Perundang-undangan, Nusa Media,

Bandung.

Peter Mahmud Marzuki, 2008, Pengantar

Ilmu Hukum, Kencana Prenada Media Group, Jakarta.
Yuliandri, 2011, Asas-asas Pembentukan Peraturan Perudang-Undangan Yang Baik, RajaGrafindo Persada, Jakarta.

\section{Naskah Internet}

Wikipedia, Anggaran Pendapatan dan Belanja Daerah, http://id.wikipedia. org/wiki/Anggaran_Pendapatan_dan_ Belanja_Daerah.

\section{Peraturan Perundang-undangan}

Undang-undang Republik Indonesia Nomor 12 Tahun 2011 tentang Tata Urutan Peraturan Perundang-undangan.

Peraturan Presiden Nomor 54 Tahun 2010 tentang Pengadaan Barang/Jasa Pemerintah.

Peraturan Menteri Dalam Negeri Nomor 21 Tahun 2011 tentang Pedoman Pengelolan Keuangan Daerah. 